\title{
Qualitative Assessment of the Effect of Thunderstorm on Rainwater Harvesting from Rooftop Catchments at Oke-Lantoro Community in Abeokuta, Southwest Nigeria
}

\author{
Eruola A. O. ${ }^{1, *}$, Ufoegbune G. C. ${ }^{1}$, Eruola A. O. ${ }^{2}$, Ojekunle Z. O. ${ }^{1}$, Makinde A. A. ${ }^{3}$, A. A. Amori ${ }^{1}$ \\ ${ }^{1}$ University of Agriculture, Abeokuta, Nigeria \\ ${ }^{2}$ Yaba College of Technology, Yaba, Lagos State, Nigeria \\ ${ }^{3}$ National Horticultural Research Institute, Nigeria
}

\begin{abstract}
Intensive temporal sampling of Rainwater Harvesting System from three rooftops runoff from a catchment at Okelantoro Community in Abeokuta, Southwest Nigeria was carried out to assess the effect of thunderstorm on the water quality. Assessment was undertaken according to different physical and chemical parameters including biological oxygen demand (BOD), Dissolved oxygen (DO), electric conductivity (EC), Alkalinity, Total hardness (TH) and some major cations and anions. Results showed strong dilution effects in the variation in harvested rainwater quality with thunderstorm and rainstorm s, however, the rainwater harvested under thunder storm had less pollution as compared to water harvested from rain storm. The asbestos roofing sheet water sample gave higher calcium and magnesium content which reflects in the total hardness value. Sample from the aluminum roofing sheet gave the best result but it was also affected by the influence of atmospheric dust particles associated with strong winds that is associated with tropical storms. Considering the results of the physico-chemical tests, irrespective of storm, the harvested water samples could be put to other domestic uses, as they cannot be consumed directly
\end{abstract}

Keywords Thunderstorm, Roof Patterns, Harvesting, Water Quality, Potable

\section{Introduction}

Rainwater harvesting system from household roofs in Africa, is becoming essential owing to the temporal and spatial variability of rainfall[5]. It appears to be the most popular method among the several strategies for mitigating the growing urban water crisis and the supplementary source of water supply to already existing public water supply scheme, particularly in area with dispersed population and hilly terrain[3]. Apart from being cost effective and ease of maintenance for effective long-term system operation, the roof top runoff also has less contamination of rainwater runoff as compared with ground catchments system. Furthermore, roof catchments provide a water supply at the point of consumption[6]

Despite having some clear advantages over other sources, rainwater use has frequently been rejected on the grounds of its water quality concerns. Rainwater quality is influenced by such agents as wind. Thunderstorms are associated with strong winds with updraft and down draft resulting in heavy

* Corresponding author:

layosky@yahoo.com (Eruola, A. O.)

Published online at http://journal.sapub.org/re

Copyright (C) 2012 Scientific \& Academic Publishing. All Rights Reserved precipitation. These are common occurrence in the tropical rainforest region and are associated with the onset of monsoons[9]. Most thunderstorm moves with mean flow through the layer of the troposphere that they occupy. Hence, it is assumed that the wind from thunder storm could contribute to the pollution of water harvested from roof top catchments. It therefore becomes important to qualitatively assess the effect of thunder storm on rainwater harvested from rooftop catchments in a tropical rainforest region. This when achieved will contribute to the management of the water resources of the area investigated.

\subsection{Study Area}

The study area, Oke-Lantoro community, is situated within Abeokuta (7o 10'N, 3o21'E) South Local Government Area of Ogun State, South-Western Nigeria (fig. 1a and 1b). Abeokuta is situated in the tropics and covers an area extent of $1256 \mathrm{~km} 2$. It is $100 \mathrm{~km}$ north of Lagos and $80 \mathrm{~km}$ south-west of Ibadan. To the west of Ogun State is the Republic of Benin (Dahomey), Lagos state lies to the south, Ondo State to the east and Oyo State to the North. The study area has a typical tropical climate, which is marked by two prominent seasons. The rainy season extends generally from March to November with intermittent dry spells. This is the period when the southwesterly wind prevails. The dry sea- 
son usually occurs from December to March when the area is under the influence of the northeasterly wind. The Abeokuta township and its environs are typical of the country's Southern zone with relatively moderate temperature and fairly excessive humidity particularly during the rainy season. The average annual rainfall in Study Area is about $1500 \mathrm{~mm}$. The Oke-Lantoro community is predominantly residential in outlook with houses of different structure hence water is mostly required for domestic purpose[3]. Public water supply is either from community boreholes (mini water scheme) or surface water source. There are very few or scanty shallow wells for majority of the area where government water is not assessable[1].

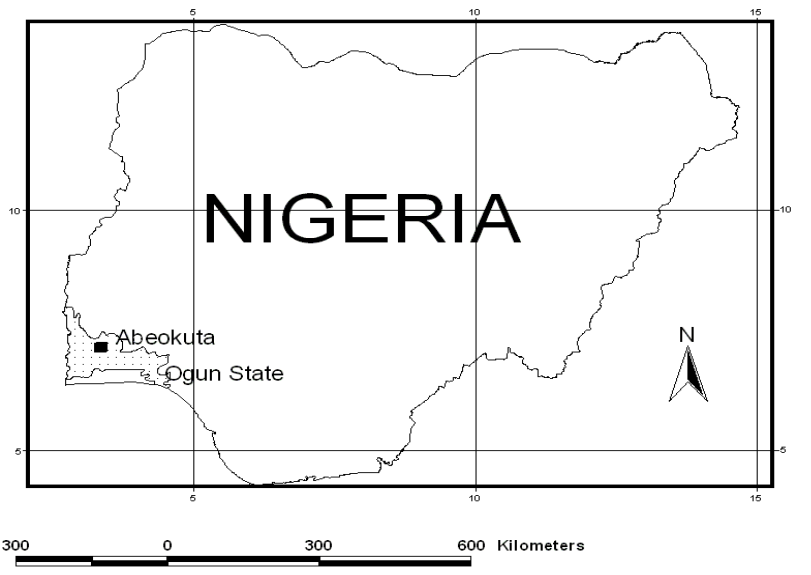

Figure 1. Nigeria showing Ogun State and Abeokuta South

\section{Materials and Methods}

The experiment for qualitative analysis of water from rainwater harvesting through roof-top run off during thunder storm and rain storm from three selected roofing sheet materials were analyzed for physical and chemical content. The roofing materials include corrugated asbestos, galvanized iron, blue aluminum and a control sample which is the water collected directly from rain drop without contact with any roof material. Twenty water samples each from selected roofing sheet materials collected for laboratory analyses were taken during rainy periods with duration ranging from 20-40 minutes and intensity ranging from $0.15-1.6$ litre/mint, and labeled immediately on the field. The samples were transported in ice chests to the different laboratories where they were either analyzed immediately or stored at $40^{\circ} \mathrm{C}$ or less to monitor the present status of source pollution indicative parameters. Standard laboratory methods were employed for the analysis. Water samples were collected in the month of May at the onset of rainfall, July during the peak period and in September at the rising period of rainfall after the August break.

\section{Results and Discussion}

Figure 2 shows the $\mathrm{pH}$, comparative assessment of dif- ferent roofing materials during the thunder and rainstorm periods in the study area. The $\mathrm{pH}$ value under thunder storm was less than under the rainstorm irrespective of roofing material used. However, blue aluminum showed a variation in trend. Highest value of $\mathrm{pH}$ was observed in asbestos and corrugated iron under rainstorm while similar value of $\mathrm{pH}$ was obtained in freefall and blue aluminum roofing materials. However, it was observed that the $\mathrm{pH}$ value irrespective of roofing materials, ranged between 6.0 to 7.0 which in most samples does not conform with WHO standard.

The Conductivity assessment of water harvested from different roofing materials during the thunder and rainstorm periods (Figure 3 ) indicated that the conductivity value under thunder storm, was less than under the rainstorm irrespective of roofing material used. However, the highest conductivity value was observed in asbestos for both thunderstorm and rainstorm. The values for the control and the blue aluminum were similar in both storms. The conductivity value obtained from all the samples ranges from 0.5 to $30 \mu \mathrm{s} / \mathrm{cm}$. It is observed that conductivity was highest in the water collected from roof top with corrugated asbestos roofing sheets irrespective of the storms. This was followed by the corrugated galvanized iron roofing sheet then the control water collected directly from the raindrop and the aluminum roofing sheet samples having the lowest conductivity value.

The Conductivity assessment of water harvested from different roofing materials during the thunder and rainstorm periods (Figure 3 ) indicated that the conductivity value under thunder storm, was less than under the rainstorm irrespective of roofing material used. However, the highest conductivity value was observed in asbestos for both thunderstorm and rainstorm. The values for the control and the blue aluminum were similar in both storms. The conductivity value obtained from all the samples ranges from 0.5 to $30 \mu \mathrm{s} / \mathrm{cm}$. It is observed that conductivity was highest in the water collected from roof top with corrugated asbestos roofing sheets irrespective of the storms. This was followed by the corrugated galvanized iron roofing sheet then the control water collected directly from the raindrop and the aluminum roofing sheet samples having the lowest conductivity value.

Presented in Figure 4 is the total hardness comparative assessment of different roofing materials during various rainfall periods. Total hardness value was highest in control for rainstorm period this was followed by corrugated galvanized iron, then the blue aluminum with the asbestos having the least value. However, total hardness was similar in harvested under thunder storm irrespective of roofing materials used. Highest total hardness in control could be attributed to splashes of sediments from the surface run off into the collection basin. Total hardness value obtained from all the samples ranges from 20 to $80 \mathrm{mg} / \mathrm{l}$. However, all the values were less than $100 \mathrm{mg} / 1$ specified drinking water standard by[11]. Hardness of water results from the effect of calcium and magnesium carbonate on water which makes it difficult to form lather with soap.Studies have also confirmed the relationship between water hardness and heart diseases[8]. 
The Alkalinity patterns as shown Figure 5 revealed that the highest value was in corrugated galvanized iron followed by the value from control and asbestos for rainstorm period with the lowest value from blue aluminum. This was also similar in for water harvested during thunder storm The range obtained fall between 0.4 to $2.0 \mathrm{mg} / \mathrm{l}$. However, all the values were less than the specified drinking water standard by[11]

Figure 6 showed Chloride comparative assessment of different roofing materials during various storm periods. The chloride values were similar irrespective rainstorm and material used. However, values of chloride were higher under rainstorm than thunder storm. The range obtained fall between 1.2 to $1.8 \mathrm{mg} / 1$ which were less than $100 \mathrm{mg} / 1$ specified drinking water standard by[11].

Presented in figure 7 is the calcium comparative assessment of different roofing materials during various storm periods. The calcium content in thunder storm water samples were higher than in rain storm samples in all selected roofing materials and control. Galvanized iron sheet and the control were similar and had the highest value under thunder storm. The range obtained fell between 20 to $45 \mathrm{mg} / \mathrm{l}$ which were less than $75 \mathrm{mg} / 1$ specified drinking water standard by[11].

Magnesium patterns as shown Figure 8 revealed, magnesium content were noticed to be extremely low in thunderstorm collected water as compared to the rainstorm water samples. The highest value of magnesium was observed in rainstorm free fall control followed by the corrugated gal- vanized iron. The range obtained fall between 1 to $35 \mathrm{mg} / \mathrm{l}$. However, thunderstorm water samples were within $20 \mathrm{mg} / \mathrm{l}$ specified limit with a range of 1 to $5 \mathrm{mg} / \mathrm{l}$ drinking water standard by[11].

Figure 9 showed dissolved oxygen comparative assessment of different roofing materials during various storm periods. The dissolved oxygen values were similar irrespective rainstorm and material used. However, values of dissolved oxygen were higher under thunderstorm than rain storm. The range obtained fall between 9 to $12 \mathrm{mg} / \mathrm{l}$ which were less than $2.0 \mathrm{mg} / 1$ specified drinking water standard by[11].

Figure 10 showed Biochemical oxygen demand (BOD) comparative assessment of different roofing materials during various storm periods. The BOD were similar irrespective rainstorm and material used. However, values of BOD were higher under rainstorm than thunder storm. The range obtained fell between 0.8 to $2.0 \mathrm{mg} / \mathrm{l}$ which were less than $15 \mathrm{mg} / 1$ specified drinking water standard by[11].

In view of the above study, it was observed that water samples collected during thunder storm were less polluted compared to rainstorm in most parameters analyzed. This may be connected with the fact that thunder storm occur when rainfall is fully established and the impurities in the atmosphere is reduced although high wind is persistence[10]. Most thunderstorm moves with mean wind flow through the layer of the troposphere that they occupy.

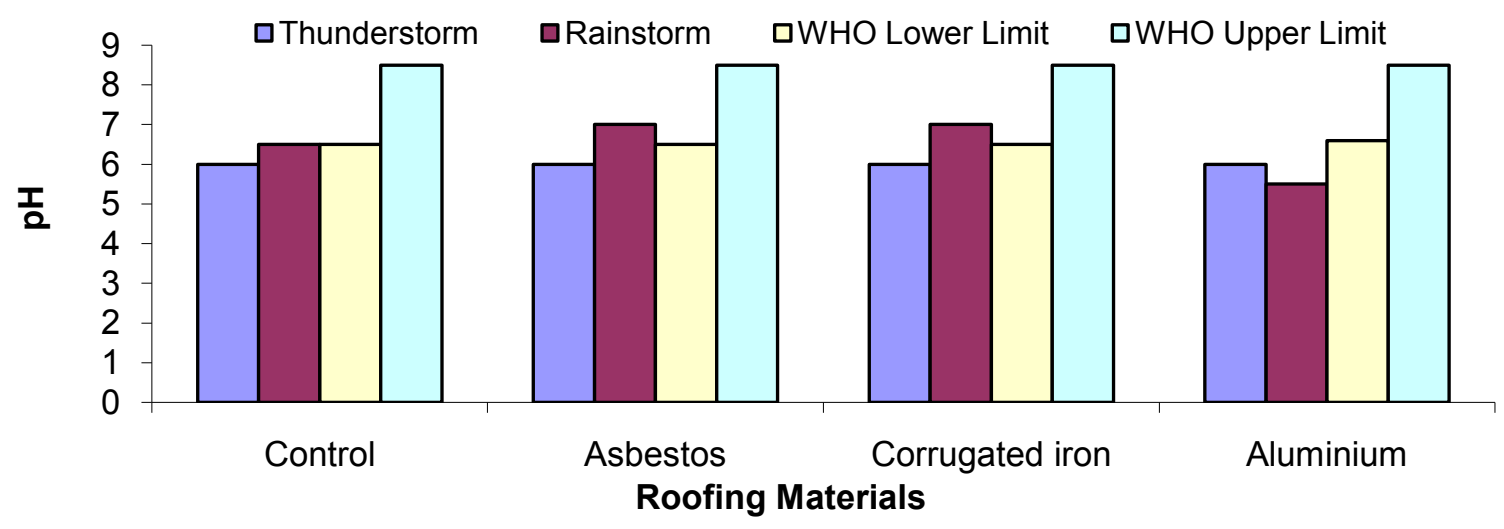

Figure 2. Assessment of $\mathrm{pH}$, of water harvested from different roofing materials during thunder and rain storm periods

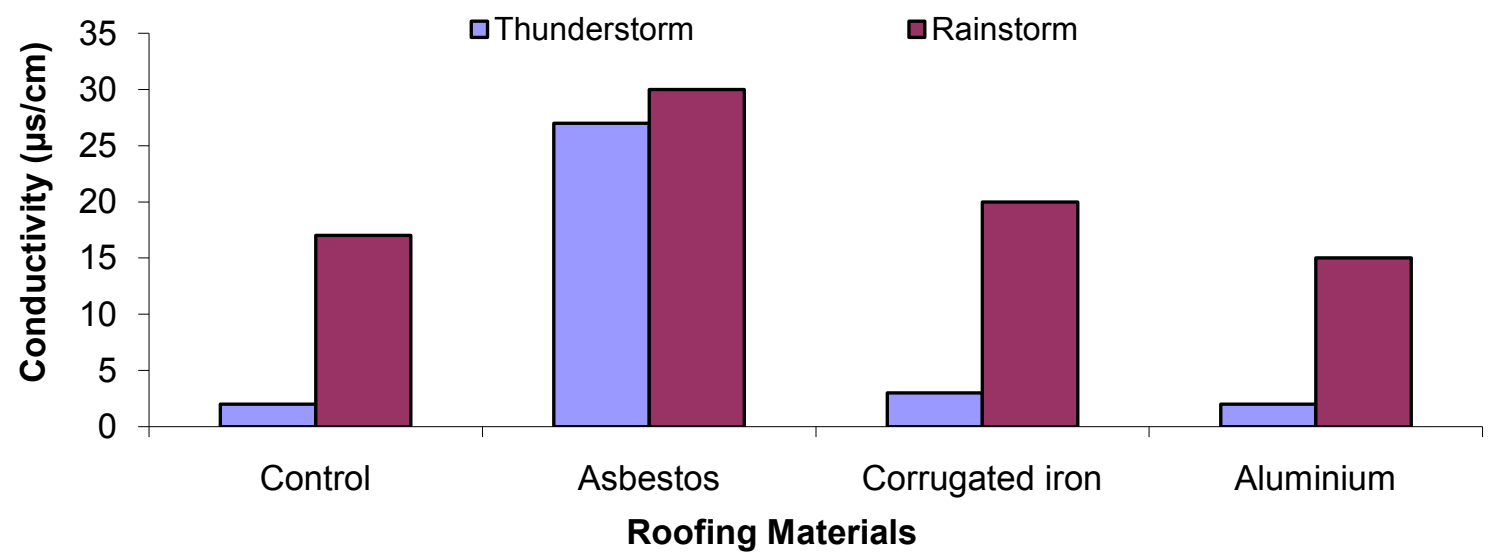

Figure 3. Assessment of Conductivity $(\mu \mathrm{s} / \mathrm{cm})$, of water harvested from different roofing materials during thunder and rain storm periods 


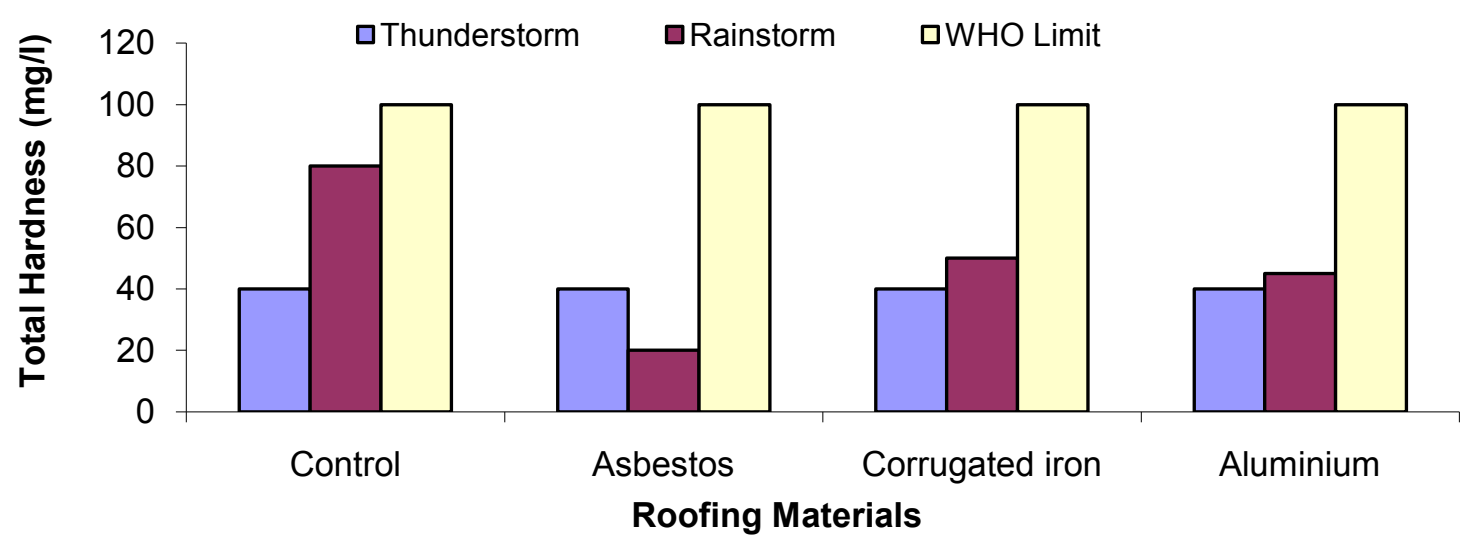

Figure 4. Assessment of Total Hardness (mg/l), of water harvested from different roofing materials during thunder and rain storm periods

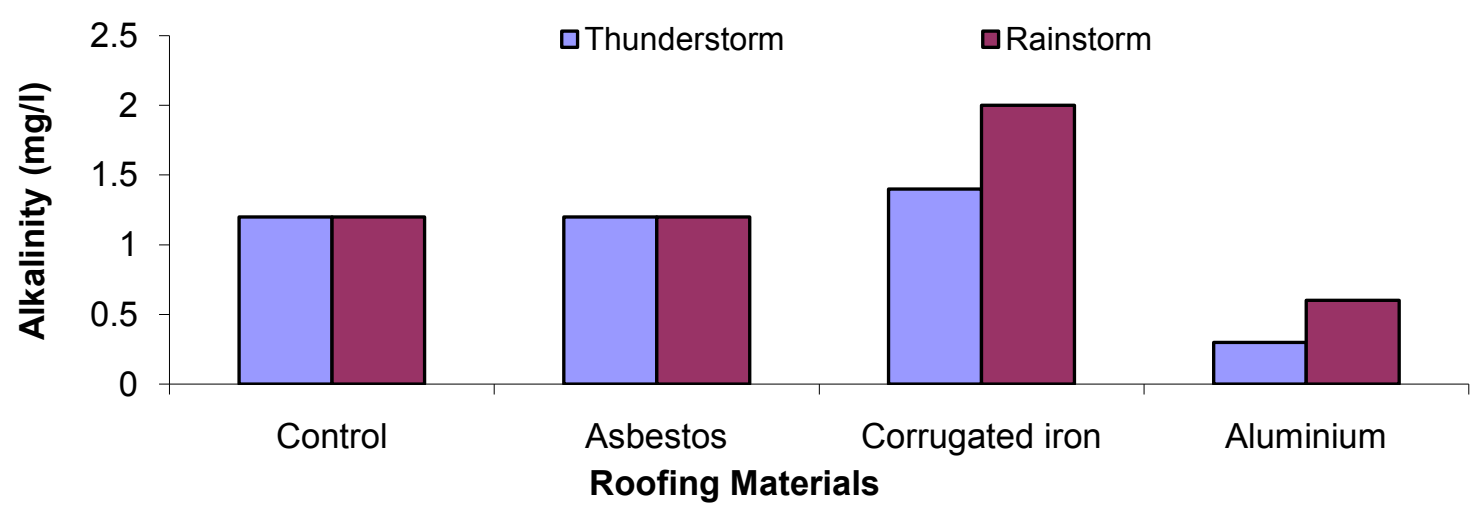

Figure 5. Assessment of Alkalinity ( $\mathrm{mg} / \mathrm{l})$, of water harvested from different roofing materials during thunder and rain storm periods

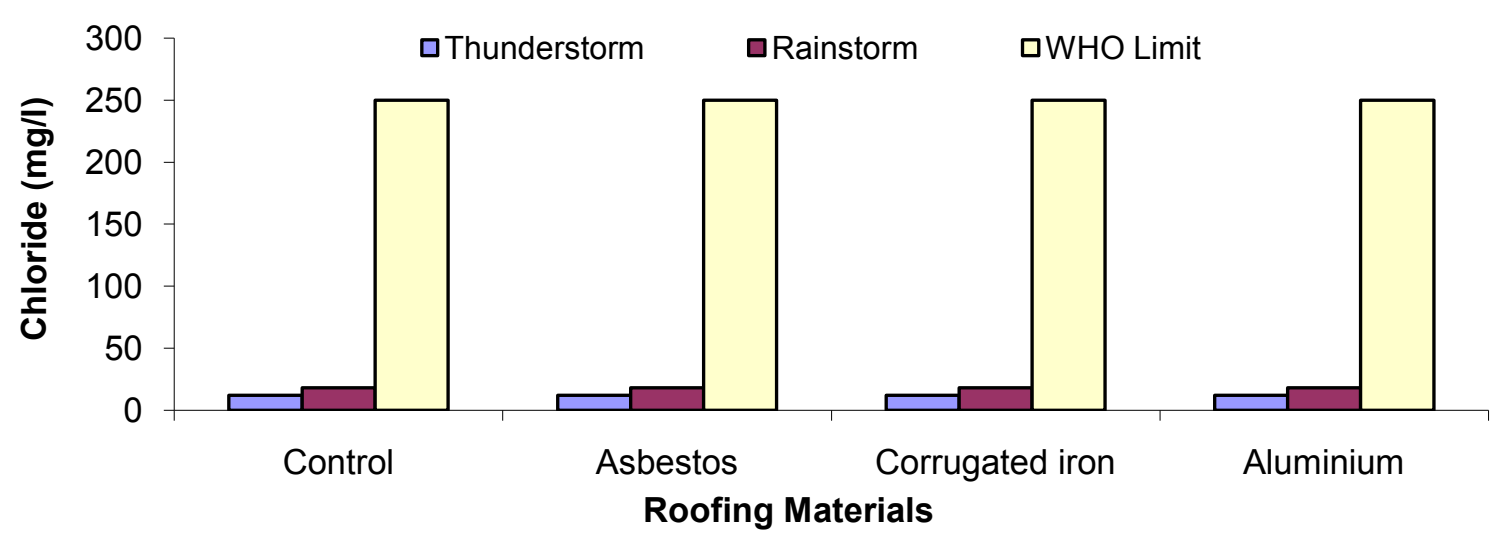

Figure 6. Assessment of Chloride $(\mathrm{mg} / \mathrm{l})$, of water harvested from different roofing materials during thunder and rain storm periods

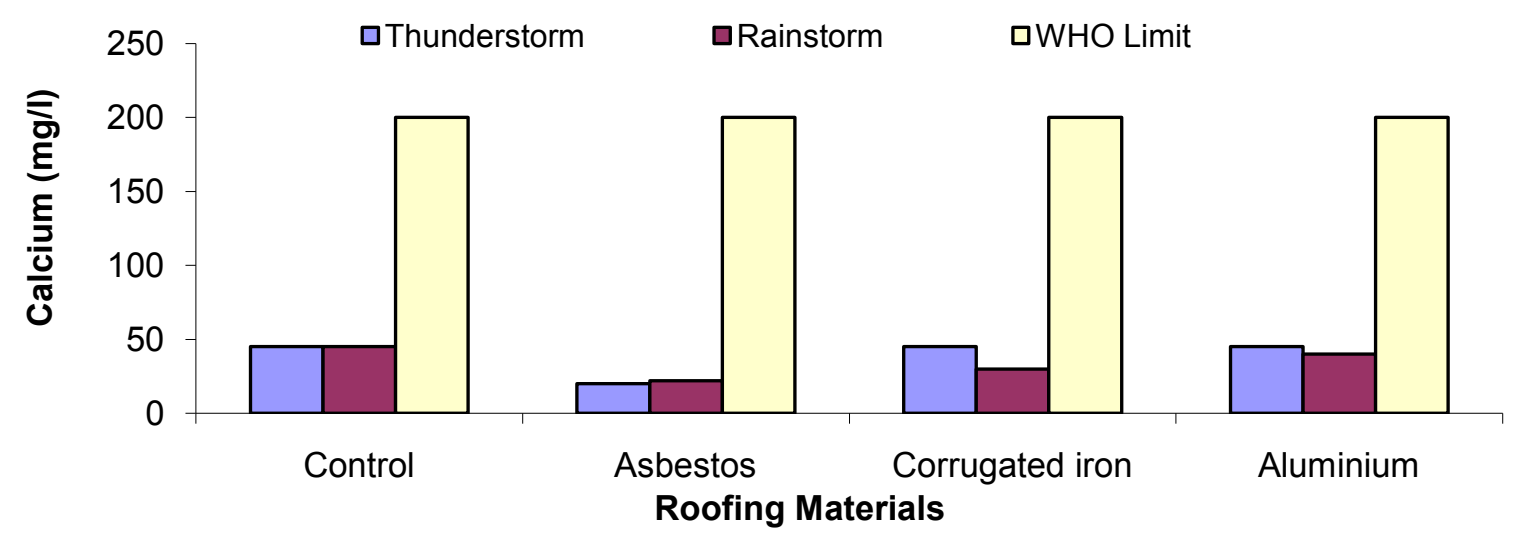

Figure 7. Assessment of Calcium ( $\mathrm{mg} / \mathrm{l})$, of water harvested from different roofing materials during thunder and rain storm periods 


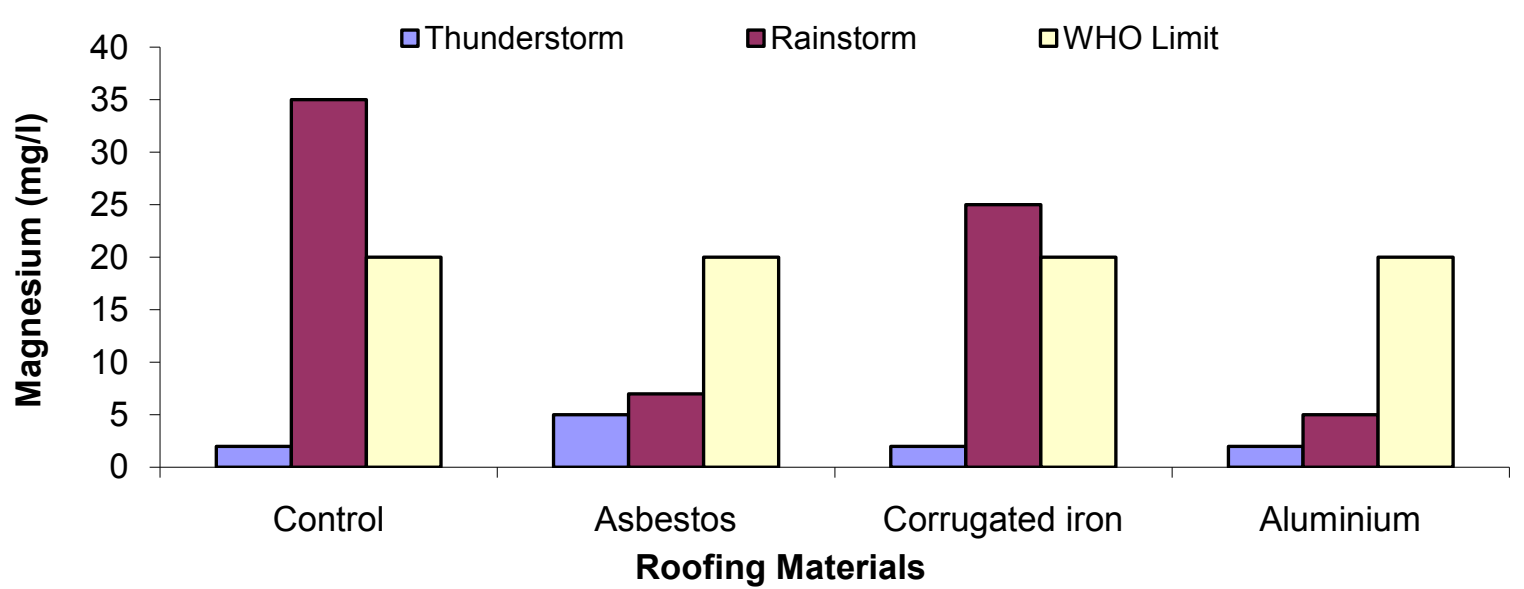

Figure 8. Assessment of Magnesium content ( $\mathrm{mg} / \mathrm{l})$ of water harvested from different roofing materials during thunder and rain storm periods

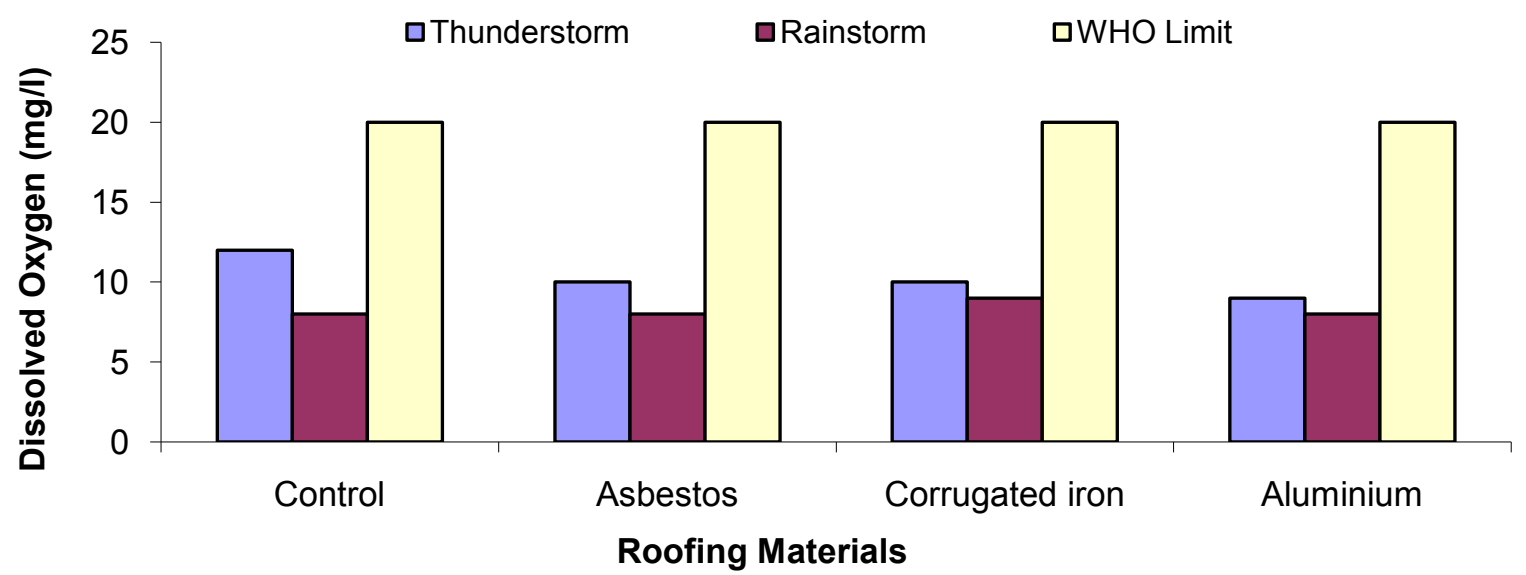

Figure 9. Assessment of Dissolved oxygen content ( $\mathrm{mg} / \mathrm{l})$ of water harvested from different roofing materials during thunder and rain storm periods

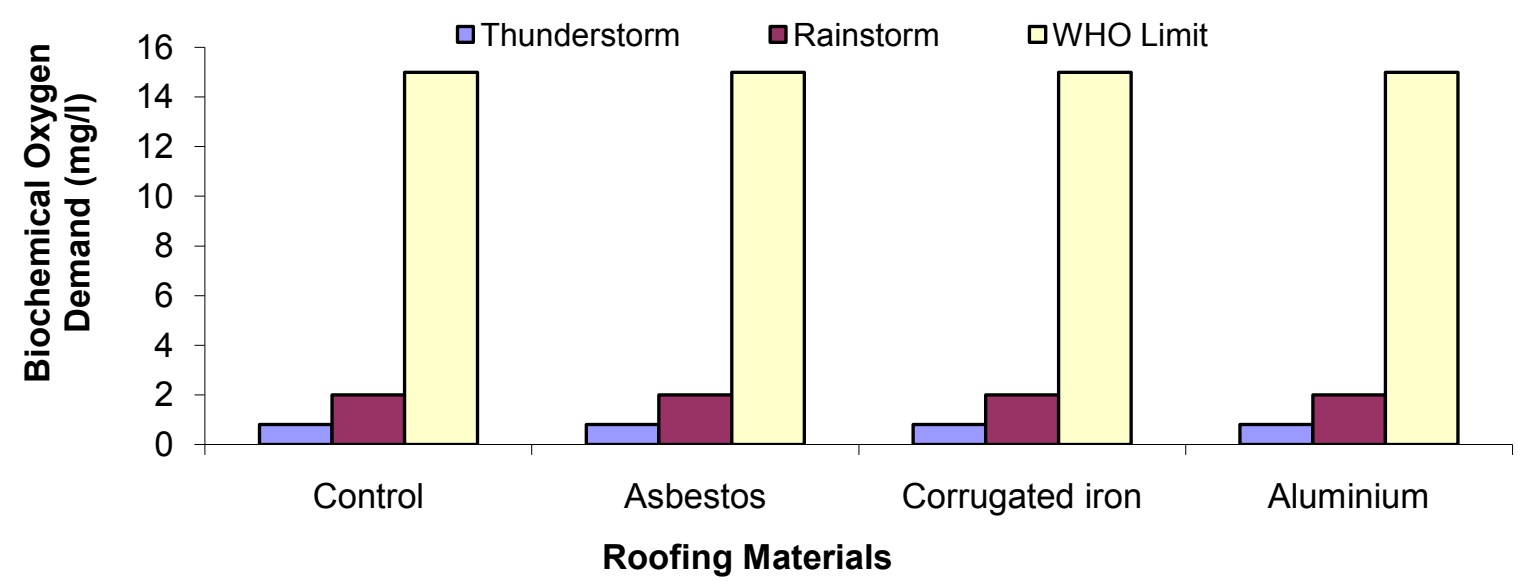

Figure 10. Assessment of BOD content $(\mathrm{mg} / \mathrm{l})$ of water harvested from different roofing materials during thunder and rain storm period

\section{Conclusions}

In the present study area, the choice of roofing materials is not considered based on the water needs of the individual rather it is based on individual financial status and taste despite the problem water supply encountered in the area. However, to mitigate the water problem in the area, effective roof top rain water harvesting system should be employed. For meaningful water harvesting from roof top, it was obvious from research that rain water harvested during thunder storm were purer than during rainstorm. Furthermore, in view of the findings presented in the above, it is observed that though the quality of water harvested from the selected roofing materials at different rainfall period falls within the[11] standard limit, some level of contamination was prominent. The water from asbestos roofing sheet has the highest level of pollution, followed by galvanized iron roofing sheet and the aluminum roofing sheet is the least polluted irrespective of type of storm. All water samples are 
quite safe for all other domestic uses such as; laundry, bathing, toilet flushing and other cleaning works.

\section{Recommendation}

Based on this study, the following suggestions are recommended to the people of this community;

1. Community should explore the rainwater harvesting system as an alternative to the acute shortage of water supply in the area

2. Water collected during thunder storm were purer than during rainstorm

3. Cultivate the use of Aluminum roofing sheets in the building design, but if incapacitated due to cost of aluminum, the coated galvanized iron roofing sheet should be adopted.

4. Safety and health measures should be paramount in storage of harvested water

5. The state and the local government should launch an enlightenment campaign on the essentials of rainwater harvesting as means of water conservation.

Finally, harvested rainwater system is a solution to the insistence problem public water supply not minding the type of storm.

\section{REFERENCES}

[1] H.B. Ayeni. "A study of chemical characteristics of shallow wells and streams in Abeokuta," unpublished B. Sc project report, University of Agriculture, Abeokuta. Pp. 13-14. 1994

[2] J.O. Ayoade, A. Iwayemi and F.O. Akintola. "Urban Water Supply and Demand in Nigeria in an Era of Economic Liberalization". Agroclimatology. Ibadan.: Vantage Publishers.
Pp. 1-4. 1998

[3] A.O. Eruola, G.C. Ufoegbune, A.O. Eruola, J.A. Awomeso, C.O. Adeofun, O.A. Idowu and A. Sowunmi. 'Qualitative and Quantitative Assessment of Rainwater Harvesting from Rooftop Catchments: Case Study of Oke-Lantoro Community in Abeokuta, Southwest Nigeria' European Water $32: 47-56$,

2010http://www.ewra.net/ew/pdf/EW_2010 32_05.pdf

[4] J. Fatokun. "Water for Agricultural Communities". Pp. 31-32. 2004

[5] Food and Agricultural Organization (FAO). "Report on water and sanitation in Africa". 2007

[6] J. Gould and E. Nissen-Petersen. Rainwater catchment systems for domestic rain: design construction and implementation. Intermediate Technology Publications, London: 335 p. 1999

[7] J. Gould. "Contributing paper; Contributions Relating to RainwaterHarvesting" http://www.rainwaterharvesting.org/urban/urban.htm. 1999

[8] K. König. Rainwater in Cities, Ecological Concepts, fbr, Kassler Str. 1a, D-60486, Frankfurt am Main, Germany. Pp. 233-241. 1998

[9] R . Ragab, J. Bromey, P Roser, J.D.Cooper and H.C. Cash. "Experimental study water fluxes in a residential area: rainfall, roof run off and evaporation, the effect of slope and aspect." Journal of Hydrological Process. Vol. 17: Pp. 2409-2422. 2003

[10] R. Richards, J. krammer, D. Baker and K. Krieger, K.” Pesticides in Rainwater in the northeastern United States, Nature, Vol. 327, No 6118, pp129-131. 1987

[11] WHO (World Health Organization). Guidelines for drinking-water quality. Recommendations. Vol.1, 3rd edition, WHO Geneva 2004 